\title{
MODAL SOSIAL DALAM GERAKAN KOPERASI
}

\section{SOCIAL CAPITAL IN THE COOPERATIVE MOVEMENT}

\section{Dodi Faedlulloh}

Asisten Dosen Universitas Jenderal Soedirman Deputi Penelitian dan Pengembangan Kopkun Institute dodifaedlulloh@gmail.com

\begin{abstract}
ABSTRAK
Gerakan koperasi di Indonesia sudah berjalan lama, namun tidak ada bukti faktual keberhasilan koperasi di Indonesia. Sebagai asosiasi orang, modal ekonomi bukanlah hal utama dalam koperasi. Ada unsur-unsur lain yang juga lebih penting dipertimbangkan, modal sosial. Dalam tulisan ini penulis meneliti satu aspek modal sosial bahwa kepercayaan memainkan peran penting dalam pengembangan koperasi. Kepercayaan bisa hadir dari nilai-nilai yang berlaku dalam masyarakat, serta koperasi. Nilai-nilai koperasi seperti kemandirian, tanggung jawab pribadi, demokrasi, solidaritas, kesetaraan, keadilan dan solidaritas yang akan menumbuhkan modal sosial dari anggota koperasi.
\end{abstract}

\section{Kata kunci : $\quad$ Koperasi, Modal Sosial, Masyarakat, Demokrasi.}

\begin{abstract}
Cooperative movement in Indonesia has been running long time, but there is no factual evidence of the success of cooperatives in Indonesia. As an association of people, economic capital is not the main thing in the cooperative. There are other elements that are also more importantly considered, the social capital. In this paper the author examines one aspect of social capital that trust plays an important role in the development of cooperatives. Trust can be present from the values prevailing in the society, as well as cooperatives. The values of cooperatives such as self-reliance, self-responsibility, democracy, solidarity, equality, justice and solidarity that will foster social capital of the members of the cooperative.
\end{abstract}

Keywords : Cooperatives, Social Capital, Society, Democracy. 


\section{PENDAHULUAN}

Kurang lebih tiga abad lalu, Adam Smith (dalam Muller, 1992) pernah menjelaskan dengan terang adalah suatu kemustahilan memahami ekonomi terpisah dari persoalan masyarakat dan nilai-nilai budaya. Oleh karena itu sektor ekonomi tanpa menekankan nilainilai budaya berpotensi menjadi mesin penghisap, terbutakan oleh hasrat ingin menguasai dan mengejar profit semata. Seiring berjalan waktu, saat globalisasi tepat di depan mata, kekuatan sosial-budaya semakin terkikis dan termanipulasi oleh kebutuhan-kebutuhan artifisial yang disuguhkan oleh hegemoni kapitalisme. Akhirnya zaman mengkonstruk manusia menjadi sosok homo economicus yang individualis, hanya "bekerja" untuk memenuhi keinginan-keinganannya.

Dengan dalih "hidup adalah kompetisi", nilai nilai semacam kebersamaan, kerekatan, dan rasa saling percaya dirasa tidak diperlukan lagi. Segala cara dilakukan demi mengejar kebahagian sendiri. Seolah lupa, kalau bangsa ini dulu terbangun dan merdeka karena adanya fondasi gotong-royong yang lekat dalam kehidupan masyarakat kita. Tak heran bila kondisi ini menjadi faktor penyebab seluruh elemen bangsa kecewa melihat situasi hari ini, disparitas sosial terjadi di mana-mana, terjebak dalam belenggu kapitalisme.
Dalam konteks yang lebih luas, pembangunan, anomali ini berlaku. Sisi sosial-budaya dinegasikan. Hadirlah korporasi-korporasi yang direncanakan menjadi stimulus pembangunan namun malah jadi alat penghancur kehidupan masyarakat banyak. Hal ini karena sifat dasar sistem kapitalisme, yang mana korporasi-korporasi adalah anak kandungnya, yang akumulatif dan eksploitatif.

Pembangunan yang hanya berorientasi pada ekonomi akan lumpuh dengan sendirinya. Dengan menyertakan modal ekonomi sebagai senjata utama, tanpa memperhatikan hal lain di luar itu, bisa mendistorsi kepercayaan masyarakat tentang kekuatan kolektifitas sosial. Ada baiknya kita mengingat proses pembangunan selama ini, modal ekonomi sudah banyak yang diinvestasikan baik, natural resources maupun capital resources. Namun hasilnya ternyata tidak maksimal. Berangkat dari hal tersebut, kiranya adalah langkah bijak bila kita melakukan refleksi bersama, sudah benarkah jalan yang ditempuh dalam melaksanakan pembangunan saat ini?

Entah luput, atau bahkan sengaja mengkondisikan pembangunan ekonomi melulu berlandaskan modal ekonomi. Hal ini semakin menjadi-jadi ketika kurikulum studi ekonomi, baik di sekolah menengah ataupun perguruan tinggi, lebih menerapkan segala yang bersifat kapitalistik, 
sehingga mindset orang banyak berpikir tanpa adanya modal finansial sulit untuk memperbaiki hidup. Logika demikian keliru, bahkan menyesatkan karena menempatkan budaya materi sebagai segala-galanya. Tak heran jika kini banyak manusia tumbuh menjadi seorang individualis dan egois yang mengejar hasrat material belaka.

Selain modal ekonomi, ada hal penting yang tidak bisa dinafikan dalam proses pembangunan, tiada lain yakni modal sosial. Di Indonesia, modal sosial masih jarang dikaji, namun di luar sana hadir pemahaman yang terus berkembang, ternyata modal sosial merupakan salah satu faktor penentu dalam pembangunan ekonomi. Beberapa ilmuan sosial seperti Bourdieu (1986), Putnam (1993), Coleman (1988) dan Fukuyama (2001), percaya bahwa modal sosial memiliki peran penting dalam keberhasilan pembangunan (sosial, budaya, ekonomi, dan politik).

Fukuyama mengatakan bahwa saling percaya (trust) merupakan elemen inti dari modal sosial (social capital). Artinya, bila pembangunan dalam segala aspek ingin berhasil, maka pembangunan tersebut harus didasari oleh adanya trust, dan selanjutnya pembangunan tersebut harus mampu mengkreasi sedemikian rupa sehingga trust terus terakumulasi. Masih menurut Fukuyama, modal sosial ini memiliki dimensi yang luas menyangkut segala sesuatu yang membuat masyarakat bersekutu untuk mencapai tujuan bersama atas dasar kebersamaan, dan di dalamnya diikat oleh nilai-nilai dan norma-norma yang tumbuh dan dipatuhi.

Sebagai mahluk sosial, manusia tidak bisa hidup sendiri. Manusia membutuhkan manusiamanusia lainnya untuk bekerjasama. Di tengah relasi tersebut akan muncul peran modal sosial. Menyibak peran modal sosial, kiranya tidak terlalu dini untuk merelevansikan dan menyebutkan koperasi sebagai lembaga yang tepat. Koperasi adalah entitas yang mendefinisikan diri sebagai perkumpulan orang. Tidak seperti korporasi yang pendiriannya berasal dari perkumpulan modal (capital based association), koperasi menekankan pada fungsi pembangunan yang berpusat pada manusia (human centre development). Dengan landasan ini, sudah barang tentu menjadi tugas koperasi untuk mampu mengartikulasikan modal sosial lebih lebih luas demi kepentingan dan kemajuan bersama.

Sebenarnya perkoperasian di Indonesia telah diamanahkan dalam rumusan perkoperasian di dalam Pasal 33 UUD 1945 ayat 1, yang mana koperasi dijadikan sebagai sokoguru perekonomian Indonesia. Koperasi pun memiliki fungsi sebagai gerakan ekonomi rakyat seperti yang termaktub dalam UU No. 25/ 1992 tentang perkoperasian, 
yang menempatkan koperasi sebagai badan usaha.

Respon dari masyarakat terhadap koperasi cukup signifikan, hal ini terlihat dari meningkatnya jumlah koperasi di Indonesia dalam kurun waktu tahun 2006 sampai tahun 2012. Peningkatan kuantitas pertahun cukup signifikan seperti yang diinformasikan data berikut ini:

Tabel 1. Data Jumlah Koperasi di Indonesia dari Tahun 2006 sampai 2012

\begin{tabular}{|l|l|l|l|}
\hline No & \multicolumn{1}{|c|}{ Tahun } & \multicolumn{1}{|c|}{ Jumlah Koperasi } & \multicolumn{1}{|c|}{ Jumlah Anggota (orang) } \\
\hline 1. & 2006 & 141.326 & 27.776 .133 \\
\hline 2. & 2007 & 149.793 & 28.888 .067 \\
\hline 3. & 2008 & 154.964 & 27.318 .619 \\
\hline 4. & 2009 & 170.411 & 29.240 .271 \\
\hline 5. & 2010 & 175.102 & 29.124 .067 \\
\hline 6. & 2011 & 188.181 & 30.849 .913 \\
\hline 7. & 2012 & 194.295 & 33.869 .439 \\
\hline
\end{tabular}

Sumber: Kementerian Koperasi dan Usaha Kecil Menengah Republik Indonesia Tahun 2012

Data di atas menginformasikan sebenarnya koperasi memiliki potensi yang tinggi sebagai organisasi ekonomi, sosial dan budaya bagi masyarakat.Namun dalam realitasnya, ada kondisi terbalik.Merujuk pada hasil penelitian Lembaga Studi Pengembangan Perkoperasian Indonesia (LSP2I) menunjukkan, 70 persen dari jumlah koperasi yang adalah koperasi fiktif, 23 persen koperasi mati suri, dan hanya kurang lebih 7 persen yang mandiri dan tak mengandalkan bantuan pihak luar. (Suroto, Kompas 17 Juli 2013).

Banyak hal yang yang menjadi penyebab disfungsi koperasi, diantaranya ada ketidak-sesuaian tujuan, fungsi dan peran koperasi dengan dinamika dan perkembangan koperasi di Indonesia. Koperasi sebagai entitas ekonomi, sosial dan budaya terus dipolitisasi dan diintervensi sehingga malah membuat koperasi tidak berkembang. Maka sangatlah wajar bila saat ini masih sulit untuk menemukan contoh-contoh koperasi yang ideal di Indonesia. Kebanyakan koperasi di Indonesia juga lupa dengan jati dirinya sendiri dan tidak menjalankan prinsip-prinsip koperasi secara benar.

Peranan koperasi sebenarnya sangat strategis karena dalam 
koperasi tidak hanya menekankan pada aspek-aspek pelaksanaan kebajikan sosial (social virtues) namun lebih itu, koperasi memiliki peranan penting untuk mengangkat nilai-nilai kebajikan sosial tersebut ke ranah publik (public sphere) yang lebih luas dalam pola jejaring kerjasama lintas suku, agama, ras, golongan, interes politik, maupun stratifikasi sosial apapun.

Dengan prinsip utamanya "capital is not master, but servant", koperasi mempunyai tujuan bukan pada akumulasi keuntungan (profit oriented) tapi diorientasikan kepada fungsi peningkatan manfaat layanan (benefit oriented). Hal ini secara jelas menunjukan koperasi berperan penting dalam menempatkan harkat manusia di atas modal (capital). Di sinilah koperasi menjadi antithesis dari paham kapitalisme yang selalu mengedepankan sisi capital dan selalu berlaku rakus demi memenuhi keserakahan si kapitalis.

Namun di tengah kondisi koperasi yang sedemikian rupa ada best practice koperasi-koperasi di beberapa tempat di Indonesia yang justru hadir tanpa banyak terendus oleh negara. Misal keberhasilan Credit Union di beberapa wilayah Indonesia, koperasi rakyat Wangunwati di Tasikmalaya, Jawa Barat. Yang menarik di antara praktik yang baik di koperasikoperasi tersebut adalah para anggotanya mengindikasikan modal sosial berperan lebih penting daripada modal finansialnya.

\section{KAJIAN TEORITIS}

\section{Modal Sosial: Trust dan Nilai-Nilai dalam Koperasi}

Modal sosial masih baru dalam diskursus ilmu sosial, sekitar tahun 1980-an modal sosial memperoleh legitimasi akademisnya. Dan sampai saat ini belum ada konsensus pasti dan formal tentang sumber dari originalitas serta proses-proses pembentukan modal sosial, namun telah muncul kesepahaman dan saling pengertian antara para ahli dan peneliti tentang peran penting modal sosial dalam proses pertumbuhan dan pembangunan.

Secara sederhana, Bourdieu (1986) menjelaskan modal sosial sebagai "Resource that result from social structure". Putnam (1993) lebih rinci mengungkapkan modal sosial, "Features of social organization, such as trust, norms (or reciprocity), and networks (of civil engagement), that can improve the efficiency of society by facilitating coordinated actions". Sementara Fukuyama (2001) mendefinisikan "Social capital is an instantiated informal norm that promotes co-operation between individuals."

Adapun Narayan mengartikan modal sosial "The rules, the norms, obligations, reciprocity and trust embedded in social relations, social structure and society's institutional arrangements which enable members to achieve their individual and community 
objectives". Lebih lanjut Uphoff (1999) menjelaskan "Social capital can be considered as an accumulation of various types of intangible social, psychological, cultural, institutional, and related assets that influence cooperative behavior". Dari deretan pengertian di muka, para ahli memberi pengertian yang variatif, namun ada benang merah yang bisa ditarik. Simpulan sederhana, modal sosial mempunyai elemen penting yang merujuk pada norms, trust, dan network.

\section{PEMBAHASAN}

$\begin{array}{cr}\text { Sebagai human } & \text { based } \\ \text { association, koperasi tentu }\end{array}$ mengandalkan modal sosial sebagai penopang keberlangsungan hidupnya. Modal sosial berperan begitu signifikan dalam gerakan koperasi. Hal ini bukan isapan jempol. Dalam riset yang dilakukan Chloupkova et al (2003) yang berjudul Building and Destroying Social Capital: The Case of Cooperative Movements in Denmark and Poland, menginformasikan bahwa ternyata modal sosial sangat mempengaruhi terhadap gerakan koperasi di Denmark dan Polandia. Dalam penelitian tersebut menyajikan data komparasi partisipasi tindakan sipil (civiv actions) di Denmark dua kali lebih besar daripada di Polandia, serta tingkat kepercayaan di Denmark (73,9\%) lebih besar daripada di Polandia (20,1\%). Gerakan koperasi di Polandia tidak terlalu berkembang berbeda halnya dengan Denmark karena di Polandia akumulasi asli modal sosialnya sempat dihancurkan oleh rezim komunis yang sempat memerintah di sana. Dalam konklusi jurnalnya, Chloupkova et al memaparkan:

"Likewise, one could argue that the massive state intervention in the Polish economy during communism, established heavy bureaucratic systems monopolizing the right to approve all actions in society. Arbitrary use of central power frightened the citizens and taught them to trust no one. Also, it created room for corruption among bureaucrats, party officials, and state monopolies, reducing the citizens' trust in formal institutions. This hypothesis was also confirmed by our empirical findings. Concerning trust among citizens, Danes trust other Danes three and a half times more than the Poles do and Danes would in general trust the four most important formal institutions (legal system, police, administration, and government) ten times more than the Poles do. Finally, like the case for membership of voluntary organizations, we would expect more civic participation and entrepreneurship in a capitalist country than in a communist country, where entrepreneurs were persecuted as potential 
threats to the system due to their capability of organizing resistance. Accordingly, we found that Danes participate in twice as many civic actions as the Poles."

Pelajaran berharga dari pengalaman kedua negara tersebut. Posisi negara ternyata bisa mendistorsi modal sosial yang berlaku dalam tatanan masyarakat, ini yang bisa dipetik, mengingat di Indonesia pun hampir mirip, gejala ketika negara terlalu sering mengintervensi bahkan cendrung mengobok-obok gerakan koperasi malah melumpuhkan koperasi dari dalam.

Peran penting modal sosial dalam kemajuan masyarakat dapat diketahui dari esensi modal sosial yang menunjuk pada trust dan norma koperasi sipil yang esensial agar masyarakat berfungsi dengan baik dan juga penting bagi kemajuan ekonomi bagi masyarakat yang bersangkutan (de Mello dalam Alfitri, 2011). Ini menujukan bahwa trust masyarakat adalah kunci dari keberhasilan kemajuan ekonomi, koperasi pun demikian. Jika sisi trust dari masyarakat sudah terbangun maka gerakan koperasi pun lebih mudah dalam pelaksanaan pengembangannya.

Unsur utama dan terpenting dari modal sosial adalah kepercayaan (trust). Atau dapat dikatakan bahwa trust dapat dipandang sebagai syarat keharusan (necessary condition) dari terbentuk dan terbangunnya modal sosial yang kuat (atau lemah) dari suatu masyarakat. Trust memiliki kekuatan mempengaruhi prinsipprinsip yang melandasi kemakmuran sosial dan kemajuan ekonomi yang dicapai oleh suatu komunitas atau bangsa (Putnam, 2000).

Trust, merupakan energi kolektif masyarakat atau bangsa untuk mengatasi problem bersama dan merupakan sumber motivasi guna mencapai kemajuan ekonomi bagi masyarakat atau bangsa (Hasbullah, 2006). Energi kolektif masyarakat atau bangsa, disebut oleh Durkheim (1973) sebagai solidaritas organik (organic solidarity), atau banyak juga disebutkan oleh para penganut aliran ekonomi baru sebagai solidaritas spontan. Trust merupakan energi kolektif masyarakat atau bangsa untuk mengatasi problem bersama dan merupakan sumber motivasi guna mencapai kemajuan ekonomi bagi masyarakat atau bangsa. Rasa saling percaya ini tumbuh dan berakar dari nilai-nilai yang melekat pada budaya kelompok. Sejalan dengan hal ini Gambetta (2000) menyatakan, berbagai tidakan kolektif yang didasari atas rasa saling mempercayai yang tinggi (high trust) akan meningkatkan partisipasi masyarakat dalam berbagai ragam bentuk dan dimensi, terutama dalam konteks membangun kemajuan bersama dan terutama kemajuan dalam bidang ekonomi.

Menurut Alfitri $(2011)$
berbagai tindakan kolektif yang
berbagai tindakan kolektif yang 
didasari atas rasa saling percaya yang tinggi akan meningkatkan partisipasi masyarakat dalam berbagai ragam bentuk dan dimensi terutama dalam konteks membangun kemajuan bersama. Filosofis dasar dari koperasi pun adalah membangun kemajuan bersama yang disertai tindakan kolektif, maka menjadi kewajiban para anggota koperasi untuk saling mempercayai satu sama lain dengan sesama anggota.

Dalam koperasi dikenal terminologi pengurus sebagai ujung tombak dari berhasil atau tidaknya berkoperasi. Di posisi pengurus lah, semua aspirasi dan amanah dari anggota diemban. Dalam hal ini, pengurus dituntut untuk mampu menterjemahkan suara-suara dari anggota dan mengaplikasikannya dalam tindakan konkret. Rasa saling percaya diuji di sini, jika para anggota percaya penuh dengan para pengurus sebagai eksekutor maka misi koperasi bisa lebih mudah digapai.

Belajar dari periode kevakuman koperasi masa lalu, banyak koperasi di Indonesia tidak berkembang karena faktor disoreintasi koperasi yang nyatanyatanya berdiri karena pola topdown, sekedar pemenuhan proyek pemerintah semata. Contoh kecil, fenomena KUD. Akronimnya pun diplesetkan menjadi Ketua Untung Duluan. Hal ini terjadi karena koperasi didirikan bukan untuk memenuhi kebutuhan anggota melainkan pemenuhan hasrat dari pengurus atau pengejaran targetan kuantitatif dari pemerintah. Dengan gelontoran modal yang menggiurkan dari pemerintah cukup bisa menggeser "keimanan" seseorang. Yang penting koperasinya jadi dan ada papan namanya. Kelirunya pihak pemerintah pun tidak berkeinginan untuk meninjau ulang dan mengevaluasi dari kebijakannya ini. Akhirnya muncul banyak koperasikoperasi papan nama yang tidak jelas ujung-pangkalnya.

Hikmah dari musibah ini yakni tidak adanya ruang demokrasi yang melekat dalam pendirian dan keberlangsungannya koperasi. Koperasi hanya jadi mainan elitis dari pengurusnya, bahkan tidak sedikit dari masyarakat yang ingin menjadi anggota koperasi malah dipatentakn untuk tetap jadi calon anggota, untuk seumur hidup bahkan. Ini lucu, tanpa perlu berpikir dua kali trust tidak mungkin ditemukan dalam koperasi yang seperti ini. Bila ini terus dibiarkan berlangsung, imbasnya cukup parah, masyarakat justru skeptis dan memandang negatif terhadap koperasi. Memandang secara generalisir bahwa semua koperasi cuma jadi alat memperkaya pengurus saja.

Membicarakan dari mana sumber trust tersebut bisa muncul memang cukup menarik. Berbagai pandangan hadir menegaskan asal muasal trust ini. Di antaranya banyak peneiliti yang merujuk ke jaringan sebagai sumber penting dari 
tumbuh dan hilangnya trust. Merujuk Nahapiet dan Ghosal (dalam Alfitri, 2011), pada tingkatan individual trust bersumber dari nilai-nilai, diantaranya dari: (a) agama atau kepercayaan yang dianut, (b) kompetensi seseorang, dan (c) keterbukaan, yang telah menjadi norma di masyarakat dan diyakini oleh seseorang. Trust di dalam tingkatan relasi sosial, merupakan atribut kolektif untuk mencapai tujuan-tujuan kelompok yang didasari oleh semangat altruism, social resiprocity, dan homo ets homo homini. Dinyatakan oleh Coleman (1988), pada tingkatan relasi sosial sumber trust berasal dari norma sosial yang memang telah melekat pada stuktur sosial komunitas (masyarakat/bangsa) yang diikat dengan nilai-nilai budaya. Hal ini terutama berkaitan dengan kepatuhan anggota komunitas terhadap berbagai kewajiban bersama yang telah menjadi kesepakatan tidak tertulis pada komintas tersebut.

Selanjutnya Wolfe (1989) yang dikutip oleh Alfitri menjelaskan sumber trust merujuk pada norma. Terutama kaitannya dengan kepatuhan anggota ke kelompok pada berbagai kewajiban bersama yang telah menjadi kesepakatan tidak tertulis pada kelompok tersebut. Penjelasan dari Wolfe ini kiranya mencukupi untuk melacak bagaiman trust bisa hadir dalam gerakan koperasi. Anggota koperasi memang bersifat sukarela dan terbuka, inklusif, tapi wajib tunduk terhadap norma atau nilai yang melekat dengan koperasi. Pada dasarnya nilai-nilai ini tidak tertulis, namun dalam perkembangannya prosesi koperasi modern melahirkan ICIS (International Co-opeative Identity Statement) yang merepresentasikan dan menjunjung nilai-nilai universal seperti: keswadayaan, swatanggungjawab, demokrasi, kebersamaan, kesetaraan, keadilan dan kesetiakawanan. Nilai-nilai ini adalah warisan dan tradisi para pendiri koperasi yang percaya pada nilai-nilai etik seperti: kejujuran, keterbukaan, dan peduli terhadap orang lain/ tanggungjawab sosial. Tampaknya kita tak sekedar harus kembali mengingat, namun juga menjalankan nilai-nilai tersebut secara kolektif. Penekanannya inilah konsekuensi logis dari gerakan koperasi, tak ada jalan lain. Ketujuh nilai ini menjadi prasyarat yang wajib dipikul dan dilaksanakan agar trust muncul. Penulis akan menguraikannya satu per satu.

Nilai swadaya didasarkan pada keyakinan bahwa setiap manusia harus berupaya keras untuk merubah hidupnya. Membuka lembaran sejarah tahun 1844, ketika penindasan karena mode of production yang kapitalistik pasca revolusi industri di Inggris, terdapat 28 buruh yang berjuang keras untuk merubah kehidupan mereka lebih baik lagi. Mereka bersama-sama membangun koperasi untuk menolong mereka sendiri. Walau pada awalnya perjuangan mereka mendapat cibiran, tapi akhirnya 
koperasi yang mereka beri nama The Rohcdale Equitable Society, justru berhasil tumbuh dan berkembang. Pada titik itulah, tonggak sejarah pertama tentang keswadayaan koperasi menjadi nyata. Trust muncul dan tumbuh di antara anggota, bahkan trust tersebut "menular" kepada masyarakat di sekitar Rochdale. Anggota pun semakin bertambah, trust semakin berlipat ganda. Dalam waktu yang relatif singkat, tahun 1860, jumlah anggota koperasi Rochdale yang asalnya hanya 28 orang meningkat menjadi 3.450 orang.

Swa-tanggungjawab berarti
bahwa anggota menerima
tanggungjawab bagi koperasi mereka dan juga bagi dirinya. Semua anggota wajib mengamini nilai ini, ketika seseorang telah menjadi anggota koperasi secara sadar harus bersiap-siap karena tanggungjawab akan segera mengikutinya. Berbeda dengan koroprasi, anggota koperasi memiliki muti-peran. Selain sebagai pemilik yang tentunya berimbas juga menjadi sebagai pemodal, dalam koperasi, anggota adalah pengguna sekaligus pengawas dari berjalannnya koperasi. Bahkan si anggota koperasi pun perlu menjadi promotor untuk koperasinya. Semua anggota koperasi harus memiliki kesadaran diri dalam mengemban tanggungjawabnya. Dalam bahasa Durkheim, perlu adanya collective conscience yakni kesadaran kolektif dari anggota bahwa mereka adalah bagian dari kelompok/koperasinya. Apa yang menyatukan anggota adalah perasaan bahwa pengetahuan, ide dan peran orang perorang tidak akan menghasilkan manfaat yang signifikan, berangkat dari hal tersebut para anggota koperasi akan menyatukan diri dan bekerja bersama.

Selanjutnya nilai demokrasi, berarti penyelenggaraan koperasi dilaksanakan harus secara demokratis. Dalam menentukan kebijakan koperasi harus mengikutsertakan semua elemen, baik itu anggota, pengurus, pengawas, dsb untuk bermusyawarah bersama. Semua kebijakan dibuat dan dilaksanakan secara deliberatif. Kemudian nilai Kebersamaan, artinya bahwa maju atau mundurnya koperasi merupakan hasil dari proses yang dilakukan secara bersamasama. Sehingga koperasi tidak mengenal istilah "aku", melainkan "kita".

Kesetaraan, berarti bahwa setiap anggota mempunyai posisi yang sama dalam merumuskan kebijakan. Sejalan dengan nilai sebelumnya, demokrasi, dalam mencapai proses demokratisasi ini harus berbanding lurus dengan nilai kesetaraan yang diberlakukan dalam koperasi. Dalam koperasi tidak mengenal latar belakang sosial, agama, ras, atau jabatan. Ketika di korporasi dikenal one share one vote, yang bisa berujung pada tirani kapital, maka di koperasi dikenal konsep one man, one vote.

Kemudian nilai keadilan. Keadilan dalam koperasi dimaknai 
setiap angggota diperlakukan secara adil sesuai dengan tingkat partisipasi ekonomi atau jasa yang disumbangkan. Koperasi bukanlah sosialisme kaku, yang selalu diartikan keliru, sama rata, sama rasa. Koperasi menaruh nilai keadilan yang distributif sesuai dengan kontribusi anggotanya. Logika ini dikontrsuk sebagai langkah rekaya sosial yang sudah inheren tertanam dalam jatidiri diri koperasi agar si anggota, yang juga adalah pemilik, ikut membangun dan mengembangkan koperasinya sendiri. Dengan adanya peran aktif para anggota baik di sisi bisnis ataupun sosial, koperasi bisa mempeluas kemanfaatannya. Ini berlaku di setiap jenis koperasi, baik itu koperasi konsumen, koperasi pekerja, ataupun di finansial.

Terakhir adalah nilai kesetiakawanan atau solidaritas. Gerakan koperasi memupuk rasa solidaritas antar anggota sebagai modal dalam mambangun dan mengembangkan koperasinya. Solidaritas inilah juga sub dari modal sosial dalam koperasi yang dapat berimbas pada reciprocity dalam anggotanya, baik yang bersifat langsung ataupun tidak. Hari ini kita membantu, besok, lusa atau kapan hari kita lah yang dibantu. Seperti yang diungkapan oleh Taylor yang dikutip oleh Putnam (2000) :

Each individual act in a system of reciprocity is usually characterized by a combination of what one might call short-term altruism and long-term self-interest. I help you now in the (possibly vague, uncertain, and uncalculating) expectation that you will help me out in the future. Reciprocity is made up of a series of acts each of which is short run altruistic (benefiting others at a cost to the altruist), but which together typically make every participant better off.

Namun semua tindakan dalam berkoperasi tidak semata didasari pada kepentingan pribadi yang sempit. Membantu di sini didasari sifat altruisme tanpa ada tendensi negatif, bertindak tanpa perilaku over, tidak dibuat-buat, karena awal berdirinya koperasi adalah berusaha untuk saling bantu antar satu dengan lainya. Dengan kata lain sifat solidaritas sudah inheren dengan operasionalisasi koperasi.

Ketujuh nilai di atas adalah pemancing trust dalam koperasi. Saat Koperasi Rochdale pertama kali berdiri pun berdasar pada semangat nilai-nilai tersebut. Pasca aplikasi nilai-nilai tersebut secara konsisten, trust akan hadir dengan sendirinya. Semakin berkembang, semakin besar, modal sosial terpupuk lalu tumbuh dan niscaya akan menghasilkan buahnya.

\section{KESIMPULAN}

Penjelasan di muka menginformasikan secara tegas modal sosial adalah proponen dari 
gerakan koperasi. Sebagai perkumpulan orang yang otonom dari orang-orang yang bersatu secara sukarela untuk memenuhi kebutuhan-kebutuhan dan aspirasi ekonomi, sosial dan budaya bersama melalui perusahaan yang mereka miliki bersama dan dikelola secara demokratis, tentu koperasi menjadikan modal sosial sebagai modal yang utama.

Namun karena sifatnya overdetermistik, tidak berlaku linear. Modal sosial memang penyokong dari gerakan koperasi, tapi koperasi itu sendiri bisa memperkaya dan meningkatkan modal sosial yang ada. Bahkan tidak ada ihwal yang lebih penting selain mempertinggi arti modal sosial demi kemajuan sistem kehidupan dan peradaban masyarakat.

Core dari modal sosial adalah trust, dalam gerakan koperasi, analisa penulis, trust bisa dibangun melalui implementasi nilai-nilai koperasi. Dengan menjalankan nilainilai; keswadayaan, swatanggungjawab, demokrasi, kebersamaan, kesetaraan, keadilan dan kesetiakawanan/solidaritas secara konsinten, bibit-bibit trust hadir tak terelakan.

Sejatinya potensi modal sosial secara abstrak sudah ada mengalir dalam sendi-sendi kehidupan masyarakat kita. Karena kemudian arus sistem ekonomi nan kapitalistik hadir di dalam tata masyarakat kita, akhirnya merubah nalar orang banyak menjadi pemangsa antar satu sama lain. Kehadiran koperasi menjadi momentum yang bertujuan untuk mempertemukan kembali manusia dengan jatidirinya sebagai mahluk sosial. Sudah saatnya merangkai kembali ceceran modal sosial yang ada dalam masyarakat. Untuk mencapainya tidak ada jalan lain lagi selain berkoperasi.

\section{DAFTAR PUSTAKA}

Alfitri. 2011. Community Development, Teori dan Aplikasi. Yogyakarta : Pustaka Pelajar

Bourdieu P. 1986. 'The Forms of Capital', in Richardson, J.G. Handbook of Theory and Research for the Sociology of Education. Westport. Connecticut: Greenwood Press.

Chloupkova, Jarka et al. 2003. Building and Destroying Social Capital: The Case of Cooperative Movements in Denmark and Poland. Kluwer Academic Publishers. Printed in the Netherlands.

Coleman, James.S. 1988. Modal sosial in the Creation of Human Capital, The American Journal of Sociology, Vol. 94 (S195S120), Supplement: Organizations and Institutions: Sociological and Economic Approaches to the Analysis of Social Structure, JSTOR. 
Durkheim, E. 1973. Moral

Education: Study in the Theory and Application of the Sociology of Education. New York: Free Press.

Fukuyama, F. 2001. Sosial Capital;

Civil Society and

Development. Third World

Quarterly, Vol 22.

-----------. 2002. Trust; Kebijakan

Sosial dan Penciptaan

Kemakmuran. Yogyakarta:

Penerbit Qalam.

Gambetta, D. 2000. Trust: Making and Breaking Cooperative Relations. Electronic Edition.

Chapter 13. Oxford:

Department Sociology,

University of Oxford, 213-37.

In

Hasbullah, J., 2006. Sosial Kapital: Menuju Keunggulan Budaya Manusia Indonesia.

Jakarta: MR-United Press.

Muller. 1992. Adam Smith and His

Time and Ours, Terjemahan

Ruslani. Yogjakarta:

CV.Qalam

Narayan, 1997.Voice of the Poor: Poverty and Social Capital in Tanzania. World Bank,Washington. DC 20433, USA.

Putnam, R.D. 1993, Making Democracy Work: Civic Traditions in Modern Italy, Princeton University Press, Princeton, USA
1995, Bowling Alone:

America's declining social

capital. Journal of

Democracy.

Uphoff, N, 1999. Understanding Social Capital: Leraning from the Analysis and Experience of Participation. in Dasgupta and I. Sergeldin, eds,pp.215-249. 